\title{
Effect of Air Pollution on Leaf Traits of Three Tree Species Growing in the Industrial Zone of Jeddah, Saudi Arabia
}

\author{
Shaheen, A. M. , Al-Toukhy, A. A. and Hajar, A. S. \\ Biological Sciences Department, Faculty of Science, King Abdulaziz University, \\ Saudi Arabia
}

\begin{abstract}
Effect of air pollution in the industrial area of Jeddah city, Saudi Arabia on three tree species Camphor (Cinnamomum camphora), Henna (Lawsonia inermis), and Bougainvillea (Bougainvillea spectabilis) has been studied with special reference to characteristics of leaves. These plant species were chosen because they are common and in the industrial and control areas. leaf area, number of stomata, stomata length and width and stomata pore width and length of these plant species were investigated. The results of this study with all trees species showed significant decrease in plant leaf area and stomata number in the industrial zone comparing with the control area. The results of those tree species indicated marked alteration in epidermal traits, with increased stomata length and width and stomata pore width and length collected from industrial site than those from control site. These changes in the leaf area and epidermal traits could be as indicator of environmental stress and can be recommended in the industrial areas for the early detection of air pollution.
\end{abstract}

Keywords: air pollution, industrial areas, leaf area, stomata.

\section{Introduction}

Mage et al. (1996) indicated that the air pollution is a major environmental problem, mainly in the developing countries. Plant leaf is the most sensitive part to be affected by air pollutants instead of all other plant parts. Several studies recorded reduction of leaf area and petiole length under pollution stress (Jahan and Iqbal, 1992; Dineva, 2004 and Tiwari et al., 2006). Abdulmoniem, (2011) reported that in polluted sites, leaves became smaller with reduced length and width and stomatal index per leaves area. Saadullah and Mudassir (2013) reported that all plant species studied exhibited significant reduction at polluted site in their leaf area when compared with the same plant species of non-polluted site.

The response of stomata characteristics to the environmental stress is an important attitude of controlling the absorption of pollutants by plants (Gostin, 2009). Farmer (1993) reported that cement dust pollutants block the stomata and reduce their number of annual crops. Various authors underlined the reduction in stomata size, as a consequence of pollution stress (Gupta and Iqba, 2005; Maruthi Sridhar et al., 2007; Verma et al., 2006). Tiwari et al. (2006) reported that the pollutants can cause foliar injury, stomata damage, premature senescence, reduced photosynthetic activity, disrupts membrane 
permeability and thus the normal growth and development.

Meerabai et al., (2012) in their study on pigeon pea, found slight decrease in leaf area and size of stomata, density of stomata, stomata frequency and stomata index as affected by pollution. Verma et al. (2006) find significant decrease of stomatal density and frequency in Ipomea pes-tigridis grown under various degrees of environmental stresses. Saquib et al. (2010) reported that the air pollution lead to the significant reduction in size and biomass of root and shoot, photosynthetic rate, stomatal conductance. Ogunkunle et al. (2013) studded the anatomical features of leaves of two plants (Pennisetum purpureum Schumach and Sida acuta Burm. F.) growing around a cement factory, and found significant modifications in the stomatal size, density and index of leaves of $S$. acuta exposed to cement dust pollution. Youssef et al. (2013) reported that the trees of Ligustrum japonicum and Olea europea (Oleaceae) growing under industrial areas showed stomata closed completely with pollutants particles and consequently expected to affect the physiological operations inside the plant cell.

This study was undertaken to assess the changes caused by urban air pollution on number and size of stomata and epidermal cells in the leaves of the industrial area of Jeddah city, Saudi Arabia on three tree species Camphor (Cinnamomum camphora), Henna (Lawsonia inermis), and Bougainvillea (Bougainvillea spectabilis).

\section{Materials and Methods}

\section{The study area}

This study was conducted at Jeddah city industrial area, which is situated between $21^{\circ} 24^{\prime} 37^{\prime \prime} \mathrm{N}$ latitude and $39^{\circ} 14^{\prime} 30^{\prime \prime} \mathrm{E}$ longitude and the control area (the Agricultural Research
Station, Hada Al-Sham, King Abdulaziz University at a distance of $120 \mathrm{~km}$ north-east of Jeddah) which situated between $21^{\circ} 47^{\prime} 50^{\prime \prime} \mathrm{N}$ latitude and $39^{\circ} 43^{\prime} 33^{\prime \prime} \mathrm{E}$ longitude in the West of Saudi Arabia.

\section{Plant Materials}

Three plant species with the same age, namely Bougainvillea (Bougainvillea spectabilis), Camphor (Cinnamomum camphora) and Henna (Lawsonia inermis) were selected for this study, as they were common in Jeddah industrial area (polluted) and the control area (unpolluted).

\section{Morphological measurements:}

\section{Leaf area $\left(\mathrm{cm}^{2}\right)$ :}

For determination of leaf area 50 fully expanded leaf samples were collected from the middle $5^{\text {th }}$ branch of each tree in four replicates per each of the two sites. The fresh leaves were digitized with Samsung SCX4216 colour scanner. Later the scanned leaves were processed using digital image analysis software package (Image Tool, version 3.0) (UTHSCSA, 2002). The leaf area was measured to the nearest $0.1 \mathrm{~cm}^{2}$.

\section{Leaf morphology}

For Scanning Electron Microscopy (SEM) studies the samples (leaves) were cut as small pieces and placed on the double side carbon tape on aluminum stub and dried in air. All samples were sputtered with a $15 \mathrm{~nm}$ thick gold layer (JEOL JFC- 1600 Auto Fine Coater). The specimens were examined with a scanning electron microscope Quanta FEG 450, FEI, Amsterdam, Netherland. The microscope was operated at an accelerating voltage of $20 \mathrm{kV}$, according to (Dykstra, 1993 and Hayat, 2000). Stomata apertures were automatically detected in the binary image according to the logical threshold and their area was measured interactively at ten randomly chosen leaf positions within a frame 
area of $0.075 \mathrm{~mm}^{2}$, excluding Stamata overlapping the margins. The number of stomata per frame was then converted to stomata per $\mathrm{mm}^{2}$.

\section{Experimental Design}

A completely randomized design with 4 replications were used to study each plant species separately where the industrial zone of Jeddah (polluted area) and the Hada Al-Shame (control area) were the treatments.

\section{Statistical Analysis}

Statistical analysis of the obtained data were statistically analyzed through analysis of variance and mean separation procedures after the assumption of the analysis of variance were tested and applied according to ElNakhlawy (2010) using SAS (2006).

\section{Results and Discussion}

Number of stomata and leaf area in the plant leaves

\section{Analysis of variance}

Analysis of variance number of stomata and leaf area in the leaves of Bougaivillea under the effects of the industrial pollutants and the control area (Table 1) showed significant effects at $\mathrm{p} \leq 0.05$ and $\mathrm{p} \leq 0.01$ for both characters in all three trees leaves.

Table (1). Analysis of variance of number of stomata on plant leaf and leaf area of the three species in the industrial zone and control area.

\begin{tabular}{|c|c|c|c|}
\hline \multirow{3}{*}{ S.O.V. } & \multirow{3}{*}{$\mathrm{df}$} & \multicolumn{2}{|c|}{ MS } \\
\hline & & \multicolumn{2}{|c|}{ Bougainvillea } \\
\hline & & stomata number & leaf area \\
\hline Locations & 1 & $98.00^{* *}$ & $233.62^{* *}$ \\
\hline \multirow[t]{3}{*}{ Error } & 6 & 8.92 & 5.29 \\
\hline & & \multicolumn{2}{|c|}{ Camphor } \\
\hline & & stomata number & leaf area \\
\hline Locations & 1 & $50.00^{* *}$ & $85.75^{* *}$ \\
\hline \multirow[t]{3}{*}{ Error } & 6 & 0.92 & 4.79 \\
\hline & & \multicolumn{2}{|c|}{ Henna } \\
\hline & & stomata number & leaf area \\
\hline Locations & 1 & $78.125^{*}$ & $1.88^{* *}$ \\
\hline Error & 6 & 12.292 & 0.11 \\
\hline
\end{tabular}

${ }^{* *}$ : significant at $\mathrm{p} \leq 0.01$.

\section{Comparison between the means}

\section{Bougaivillea trees}

As shown in Table (2) the plant leaf in the industrial zone had number of stomata and leaf area less than under Hada Al-Sham (control) with significant values. Number of stomata/leaf in the industrial zone around 1/2 the number/leaf under the control and around 0.66 of the leaf area compared the control.

Table (2). Means of number of stomata on plant leaf and leaf area $\left(\mathrm{cm}^{2}\right)$ of the three species in the industrial zone and control area.

\begin{tabular}{|c|c|c|}
\hline \multirow{2}{*}{ Locations } & \multicolumn{2}{|c|}{ Means } \\
\cline { 2 - 3 } & number of stomata & leaf area $\left(\mathrm{cm}^{2}\right)$ \\
\hline Industrial Zone & $6.750 \mathrm{~b}^{*}$ & $19.510 \mathrm{~b}^{*}$ \\
\hline Hada Al-Sham & $13.750 \mathrm{a}$ & $29.750 \mathrm{a}$ \\
\hline & \multicolumn{2}{|c|}{ Camphor } \\
\cline { 2 - 3 } & stomata number & leaf area $\left(\mathrm{cm}^{2}\right)$ \\
\hline Industrial Zone & $7.250 \mathrm{~b}$ & $20.074 \mathrm{~b}$ \\
\hline Hada Al-Sham & $12.250 \mathrm{a}$ & $24.504 \mathrm{a}$ \\
\hline & \multicolumn{2}{|c|}{ Henna } \\
\cline { 2 - 3 } & stomata number & leaf area $\left(\mathrm{cm}^{2}\right)$ \\
\hline Industrial Zone & $13.500 \mathrm{~b}$ & $1.776 \mathrm{~b}$ \\
\hline Hada Al-Sham & $19.750 \mathrm{a}$ & $2.212 \mathrm{a}$ \\
\hline
\end{tabular}

* Means followed by the same letter are not significantly different according to LSD at $(\mathrm{p} \leq 0.05)$.

\section{Camphor trees}

As shown in Table (2) the plant leaf in the industrial zone had stomata number and leaf area less than in the plant grown in Hada AlSham (control) with significant values.

\section{Henna trees}

As shown in Table (2) the plant leaves in the industrial zone had stomata number and leaf area less than in the plant leaves of Hada Al-Sham (control) with significant values.

The frequency of stomata as a response to the environmental pollution is an important manner of controlling the absorption of pollutants by plants. The results of this study with all trees species showed a significant decrease in stomata number in the industrial zone comparing with the control area. This results are confirmed with the results of (Salgare, and Acharekar 1990; Verma et al., 
2006; Lakshmi et al., 2009; Tiwari, 2012 and Meerabai et al., 2012).

Leaf is the most sensitive part to be affected by air pollutants instead of all other plant parts such as stem and roots. The results of this study with all trees species showed significant decrease in plant leaf area in the industrial zone comparing with the control area. Similarly, significant growth reductions have also been reported for leaves from other tree species in heavily polluted areas (Platanus acerifolia, Ficus bengalensis, Guaiacum officinale and Eucalyptus sp., Nivova et al., 1983; Jahan and Iqbal, 1992). Also, Saadullah and Mudassir (2013) showed that all studied plant species exhibited significant reduction at polluted site in their leaf area when compared with the same plant species of non-polluted site.

\section{Stomata structure in the plant leaves \\ Stomata width and length Analysis of variance}

Analysis of variance of stomata width and length in the plant leaves under the effects of the industrial pollutants and the control area (Table 3) showed no significant effects at $\mathrm{p} \leq 0.05$ for both characters in all three trees leaves.

Table (3). Analysis of variance of stomata width and stomata length on plant leaves of the three species in the industrial zone and control area.

\begin{tabular}{|c|c|c|c|}
\hline \multirow{2}{*}{ S.O.V. } & \multirow{2}{*}{ df } & \multicolumn{2}{|c|}{ MS } \\
\cline { 3 - 4 } & & \multicolumn{2}{|c|}{ Bougainvillea } \\
\cline { 3 - 4 } & & stomata width & stomata length \\
\hline Locations & 1 & $0.1303^{\mathrm{NS}}$ & $0.015^{\mathrm{NS}}$ \\
\hline Error & 6 & 1.319 & 0.017 \\
\hline \multirow{2}{*}{} & \multicolumn{3}{|c|}{ Camphor } \\
\cline { 3 - 4 } & & stomata width & stomata length \\
\hline Locations & 1 & $22.696^{\mathrm{NS}}$ & $12.772^{\mathrm{NS}}$ \\
\hline Error & 6 & 7.735 & 4.065 \\
\hline \multicolumn{2}{|c|}{} & \multicolumn{2}{|c}{ Henna } \\
\cline { 3 - 4 } & & stomata width & stomata length \\
\hline Locations & 1 & $6.264^{\mathrm{NS}}$ & $6.195^{\mathrm{NS}}$ \\
\hline Error & 6 & 2.500 & 2.178 \\
\hline
\end{tabular}

\footnotetext{
${ }^{\mathrm{Ns}}$ : not significant at $\mathrm{p} \leq 0.05$.

${ }^{* * * *}$ : significant at $\mathrm{p} \leq 0.05$ and $\mathrm{p} \leq 0.01$, respectively.
}

\section{Comparison between the means}

Mathematically stomata width and length were in larger under the Hada Al-Sham than the industrial zone but without significantly differences (Table 4).

Table (4). Means of stomata width and stomata length on plant leaves the three species in the industrial zone and control area.

\begin{tabular}{|c|c|c|}
\hline \multirow{3}{*}{ Locations } & \multicolumn{2}{|c|}{ Means $(\mu \mathrm{m})$} \\
\hline & \multicolumn{2}{|c|}{ Bougainvillea } \\
\hline & stomata width & stomata length \\
\hline Industrial Zone & $8.953 \mathrm{a}^{*}$ & $18.315 \mathrm{a}$ \\
\hline \multirow[t]{3}{*}{ Hada Al-Sham } & $9.208 \mathrm{a}$ & $18.403 \mathrm{a}$ \\
\hline & \multicolumn{2}{|c|}{ Camphor } \\
\hline & stomata width & stomata length \\
\hline Industrial Zone & $6.066 \mathrm{a}$ & $14.113 \mathrm{~b}$ \\
\hline \multirow[t]{3}{*}{ Hada Al-Sham } & $9.435 \mathrm{a}$ & $18.035 \mathrm{a}$ \\
\hline & \multicolumn{2}{|c|}{ Henna } \\
\hline & stomata width & stomata length \\
\hline Industrial Zone & $6.066 \mathrm{a}$ & $14.113 \mathrm{a}$ \\
\hline Hada Al-Sham & $7.836 \mathrm{a}$ & $15.873 \mathrm{a}$ \\
\hline
\end{tabular}

* Means followed by the same letter are not significantly different according to LSD at $(\mathrm{p} \leq 0.05)$.

\section{Bougaivillea trees}

As shown in Table (4) the plant leaves in the industrial zone had stomata width value 8.953 and stomata length $18.315 \mu \mathrm{m}$ and in Hada Al-Sham (control) the values were 9.208 and $18.403 \mu \mathrm{m}$.

\section{Camphor trees}

As shown in Table (4) the plant leaves in the industrial zone had stomata width value 6.066 and stomata length $14.113 \mu \mathrm{m}$ and in Hada Al-Sham (control) the values were 9.435 and $18.035 \mu \mathrm{m}$.

\section{Henna trees}

As shown in Table (4) the plant leaves in the industrial zone had stomata width value 6.066 and stomata length $14.113 \mu \mathrm{m}$ and in Hada Al-Sham (control) the values were 7.836 and $15.873 \mu \mathrm{m}$.

These results of all tree species are confirmed with the results of Verma et al., 
(2006) and Pourkhabbaz et al. (2010). Negative effects of air pollutants on stomatal densities and opening have also been found in other species such Trifolium repens, Trifolium pratense, Cicer arietenum, Acer saccharum and Ipomea pes-tigridis growing in polluted areas (Sharma and Butler 1973, 1975; Garg and Varshney 1980; Ghouse et al., 1980; Verma et al. 2006). Gostin (2009) reported the decrease in stomatal size in Lotus corniculatus, Trifolium montanum, T.pratense, and T.repens.

\section{Stomata pore width and length}

\section{Analysis of variance}

Analysis of variance of stomata pore width and length in the plant leaves under the effects of the industrial pollutants and the control area (Table 5) showed no significant effects at $\mathrm{p} \leq 0.05$ for both characters in all three trees leaves.

Table (5). Analysis of variance of stomata pore width and stomata pore length on plant leaves of the three species in the industrial zone and control area.

\begin{tabular}{|c|c|c|c|}
\hline \multirow{2}{*}{ S.O.V. } & \multirow{2}{*}{ df } & \multicolumn{2}{|c|}{ MS } \\
\cline { 3 - 4 } & & Bougainvillea \\
\cline { 3 - 4 } & & stomata pore width & stomata pore length \\
\hline Locations & 1 & $8.496^{\mathrm{NS}}$ & $1.329^{\mathrm{NS}}$ \\
\hline Error & 6 & 10.228 & 4.858 \\
\hline \multirow{2}{*}{} & & \multicolumn{2}{|c|}{ Camphor } \\
\cline { 3 - 4 } & & stomata pore width & stomata pore length \\
\hline Locations & 1 & $7.78^{\mathrm{NS}}$ & $11.400^{\mathrm{NS}}$ \\
\hline Error & 6 & 2.556 & 4.712 \\
\hline \multirow{2}{*}{} & & \multicolumn{2}{|c|}{ Henna } \\
\cline { 3 - 4 } & 1 & stomata pore width & stomata pore length \\
\hline Locations & 1 & $2.615^{\mathrm{NS}}$ & $2.423^{\mathrm{NS}}$ \\
\hline Error & 6 & 0.563 & 5.894 \\
\hline
\end{tabular}

${ }^{\text {NS }}$ : not significant at $\mathrm{p} \leq 0.05$.

\section{Comparison between the means}

\section{Bougaivillea trees}

As shown in Table (6) the plant leaves in the industrial zone had stomata pore width and length with values of 4.524 and $12.482 \mu \mathrm{m}$, respectively while in of Hada Al-Sham (control) these were 6.586 and $12.298 \mu \mathrm{m}$, respectively.

Table (6). Means of stomata pore width and stomata pore length on plant leaves the three species in the industrial zone and control area.

\begin{tabular}{|c|c|c|}
\hline \multirow{2}{*}{ Locations } & \multicolumn{2}{|c|}{ Means $(\mu \mathrm{m})$} \\
\cline { 2 - 3 } & Bougainvillea \\
\cline { 2 - 3 } & stomata pore width & $\begin{array}{c}\text { stomata pore } \\
\text { length }\end{array}$ \\
\hline Industrial Zone & $4.524 \mathrm{a}^{*}$ & $12.482 \mathrm{a}$ \\
\hline Hada Al-Sham & $6.586 \mathrm{a}$ & $13.298 \mathrm{a}$ \\
\hline \multirow{2}{*}{} & \multicolumn{2}{|c|}{ Means $(\mu \mathrm{m})$} \\
\cline { 2 - 3 } & Camphor \\
\cline { 2 - 3 } & stomata pore width & $\begin{array}{c}\text { stomata pore } \\
\text { length }\end{array}$ \\
\hline Industrial Zone & $3.0003 \mathrm{a}$ & $8.375 \mathrm{a}$ \\
\hline Hada Al-Sham & $4.9723 \mathrm{a}$ & $10.763 \mathrm{a}$ \\
\hline \multirow{2}{*}{ Means $(\mu \mathrm{m})$} \\
\cline { 2 - 3 } & \multicolumn{2}{|c|}{ Means $(\mu \mathrm{m})$} \\
\cline { 2 - 3 } & stomata pore width & $\begin{array}{c}\text { stomata pore } \\
\text { length }\end{array}$ \\
\hline Industrial Zone & $1.857 \mathrm{a}$ & $7.273 \mathrm{a}$ \\
\hline Hada Al-Sham & $3.0003 \mathrm{a}$ & $8.375 \mathrm{a}$ \\
\hline
\end{tabular}

${ }^{*}$ Means followed by the same letter are not significantly different according to LSD at $(\mathrm{p} \leq 0.05)$.

\section{Camphor trees}

As shown in Table (6) the plant leaves stomata pore width and length were 3.0003 and $8.375 \mu \mathrm{m}$, in the industrial zone, while in the plant leaves of Hada Al-Sham (control), were 4.9723 and $10.763 \mu \mathrm{m}$, respectively.

\section{Henna trees}

Table (6) means revealed that the stomata pore width and length of the leaves in the industrial zone were 1.857 and $7.273 \mu \mathrm{m}$, respectively, while in the plant leaves of Hada Al-Sham were 3.0003 and $8.375 \mu \mathrm{m}$, respectively.

These results of the studied tree species are confirmed with the results of Iqbal et al. (1996), Pal et al. (2002), Honour et al. (2009) and Saquib et al. (2010). Verma et al., (2006) reported that the reduction in stomatal densities and their pore size may be important for controlling absorption of pollutants and 
limits the photosynthesis at the same time (Taiz and Zeiger, 2010).

\section{Conclusion}

1. Number of stomata and leaf area were higher under the control area than the industrial zone.

2. Number of stomata $/ \mathrm{cm}^{2}$ ranged from 6.75 to 13.500 under the industrial zone compared to 12.250 to 19.750 under the control conditions in the 3 plant species.

3. Leaf area ranged from $1.776 \mathrm{~cm}^{2}$ of Henna - $20.074 \mathrm{~cm}^{2}$ of Camphor under the industrial conditions, while under the Hada Al-Sham it ranged from $2.212 \mathrm{~cm}^{2}-29.750 \mathrm{~cm}^{2}$.

4. Stomata width and length not significantly affected by the location except the stomata length in Camphor.

5. Stomata pore width and length not significantly affected by the industrial zone compared with the control in the 3 plant species.

\section{References}

Abdulmoniem, M.A. (2011) Effects of Auto-exhaust Pollution on the Micro Morphology and Leaf Epidermal Features of Ornamental Plants in Khartoum, Sudan, Journal of Applied Sciences Research, 7 (3): 270-273.

Dineva, S.B. (2004) Comparative studies of the leaf morphology and structure of white ash Fraxinus americana L. and London plane tree Platanus acerifolia Wild growing in polluted area, Dendrobiology, 52: 3-8.

El-Nakhlawy, F.S. (2010) Experimental Design and Analysis in Scientific Research. Sci. Pub. Center, king Abdulaziz University, Jeddah, Saudi Arabia.

Farmer, A.M. (1993) The effect of dust on vegetation - A review. Environ. Pollut. 79: 63-75.

Garg, K.K. and Varshney, C.K. (1980) Effect of air pollution on the leaf epidermis at the sub microscopic level, Experientia., 36:1364-1366.

Ghouse, A.K.M., Zaidi, H. and Attique, A. (1980) Effect of air pollution on the foliar organs of Callistemon citrinus Stapf, J Sci Res. 2:207-209.
Gostin, I.N. (2009) Air pollution effects on the leaf structure of some Fabaceae species, Not. Bot. Hort. Agrobot. Cluj. 37(2): 57-63.

Gupta, M.C. and Iqbal, M. (2005) Ontogenetic histological changes in the wood of (Mangifera indica L.cv Deshi) exposed to coal-smoke pollution. Environmental and Experimental Botany., 54 (3): 248-255.

Honour, S.L., Bell, J.N.B., Ashenden, T.W., Cape, J.N. and Power, S.A. (2009) Responses of herbaceous plants to urban air pollution: effects on growth, phenology and leaf surface characteristics. Environmental pollution, 157: 1279-1286.

Iqbal, M., Abdin, M., Mahmooduzzafar, Z., Yunus, M. and Agrawal, M. (1996) Resistance mechanisms in plants against air pollution. In: Yunus, M., Iqbal, M. (Eds), Plant Response to Air Pollution. John Wiley, Chichester, pp: 194-240.

Jahan, S. and Iqbal, M.Z. (1992) Morphological and anatomical studies of leaves of different plants affected by motor vehicles exhaust. Journal of Islamic Academy of Sciences, 5 (1): 21-23.

Lakshmi, P.S., Sarvanti, K.L. and Srinivas, N. (2009) Air pollution tolerance index of various plants species growing in industrial areas, An Int. Biannua J. of Environ. Sci., 2: 203-206.

Mage, D., Ozolins, G., Peterson, P., Webster, A., Orthofer, R., Vandeweerd, V. and Gwynne, M. (1996) Urban air pollution in mega-cities of the world. Atmospheric Environment; 30: 681-686.

Maruthi Sridhar, B.B., Han, F.X., Monts, D.L. and Su, Y. (2007) Changes in plant anatomy due to uptake and accumulation of $\mathrm{Zn}$ and $\mathrm{Cd}$ in Indian mustard (Brassica juncea). Environmental and Experimental Botany., 54 (2): 131-141.

Meerabai, G., Venkata Ramana, C. and Rasheed, M. (2012) Effect of air pollutants on leaves of pigeon pea, a pulse crop of Fabaceae growing in the vicinity of a silicon Industry. World Rural Observations., 4 (2): $19-21$

Nivova, D.J., Dushkova, P.I. and Kovacheva, G.V. (1983) Anatomical, morphological studies of Platanus acerifolia at various digress of air pollution, Ecology, (Sofia) 6: 35-47.

Ogunkunle, C.O., Abdulrahaman, A.A. and Fatoba, P.O. (2013) Influence of cement dust pollution on leaf epidermal features of Pennisetum purpureum and Sida acuta. Environmental and Experimental Biology, 11: 73-79.

Pal, A., Kulshshreshtha, K., Ahmad, K.J. and Bhel, H.M. (2002) Do leaf surface characters play a role in plant resistance to auto exhaust pollution? Flora, 197: $47-55$. 
Pourkhabbaz, A., Rastin, N., Olbrich, A., LangenfeldHeyser , R. and Polle, A. (2010) Influence of Environmental Pollution on Leaf Properties of Urban Plane Trees, Platanus orientalis L., Bull Environ Contam Toxicol., 85 (3): 251-255.

Saadullah, K. L. and Mudassir, A. Z. (2013) Effect of air pollution on the leaf morphology of common plant species of Quetta city. Pak. J. Bot., 45 (S1): $447-$ 454.

Salgare, S.A. and Acharekar, C. (1990) Effect of industrial air pollution (from chembur, India) on the micro morphology of some wild plants. II. Adv. Plant. Sci. 3: $1-7$.

Saquib, M. Ahmad, A. and Ansari, K. (2010) Morphological and Physioligical Responses of Croton Bonplandianum Baill. to air Pollution. ECOPRINT 17: $35-41$

Sharma, G.K. and Butler, J. (1973) Leaf cuticular variations in Trifolium repens L. as indicators of environmental pollution, Environ Pollut. 5:287-293. doi: 10.1016/0013-9327(73)90005-0.

Sharma, G.K. and Butler, J. (1975) Environmental pollution: leaf cuticular patterns in Trifolium pratense L., Ann Bot. 39:1087-1090.
Taiz, L. and Zeiger, E. (2010) Plant Physiology, 5th edition. In. Chap. 26. Effect of air pollution on plants. Language Publishers, Sinauer Associates, California, USA.

Tiwari, S. (2012) Air Pollution Induced changes in Foliar Morphology of two shrub species at Indore city, India. Res.J.Recent.Sci. 2:195-199.

Tiwari, S., Agrawal, M. and Marshall, F.M. (2006) Evaluation of ambient air pollution impact on carrot plants at a sub urban site using open top chambers. Environmental Monitoring and Assessment, 119: 1530.

Verma, R.B., Mahamooduzzafar, T.O. and Iqbal, M. (2006) Foliar response of Ipomea pes -tigridis L. to Coal Smoke Pollution. Turkish Journal of Botany., 30 (5) 413-417.

Younis, U., Bokhari, T. Z., Shah, M.H.R. Mahmood, S. and Malik, S.A. (2013) Dust interception capacity and alteration of various biometric and biochemical attributes in cultivated population of Ficus carica L. IOSR Journal of Pharmacy and Biological Sciences, 6 (4): 35-42. 


\section{تأثنير تلوث الهواء على صفات الورقة لثلاثة أنواع من الأشجار تتموا في المنطقة الصناعية بجدة، المملكة العربية السعودية}

\section{شاهين، أحمد محمد عبدالرحيم؛ الطوخي، عبدالمنعم عبد المجيذ؛ آل حجر، عبدالرحمن سعيد قسم علوم الأحباء، كلبة العلوم، جامعة الملك عبدالعزبز، جدة، المدلكة العربية السعودية}

المستخلص. تم دراسة تأثنر تلوث الهواء في المنطقة الصناعية بمدينة جدة - المملكة العربية السعودية على ثلاثة أنواع من الأثجار الكافور (Cannamomum camphora)، الحناء (Lawia inermis)، والجهية (Bougainvillea spectabilis) وذلك عن طريق دراسة خصائص الأوراق. وقد تم اختيار هذه الأنواع النباتية لأنها شائعة في المنطقة الصناعية ومنطقة المقارنة (هدا الثام). وقد نم دراسة مساحة الورقة، عدد الثغور، وطول وعرض الثغور وطول وعرض فتحة الثغور لهذه الأنواع النباتية. أظهرت نتائج هذه الدراسة مع جميع أنواع الأشجار انخفاض معنوي في مساحة الورقة وعدد الثغور في المنطقة الصناعية

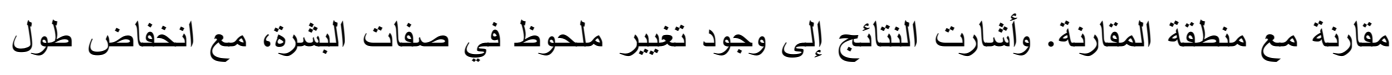
وعرض الثغور وطول وعرض فتحة الثغور في الأوراق التي تم جمعها من المنطقة الصناعية مقارنة مع منطقة المقارنة. هذه التغييرات في مساحة الورقة وصفات البشرة يمكن أن تكون كمؤشر عن الإجهاد البيئي

ويمكن أن بوصي بها في المناطق الصناعية من أجل الكثف المبكر لتلوث الهواء. الكلمات الدفتاحية: تلوث الهواء، المناطق الصناعية، مساحة الورقة، الثغور . 